Zeszyty Naukowe Szkoły Głównej Gospodarstwa Wiejskiego

Ekonomika i Organizacja Gospodarki Żywnościowej nr 115, 2016: 171-182

Katarzyna Gralak

Wydział Nauk Ekonomicznych

Szkoła Główna Gospodarstwa Wiejskiego w Warszawie

\title{
Witryna internetowa jako narzędzie promocji i dystrybucji oferty gospodarstw agroturystycznych
}

\section{Wstęp}

Internet jako globalne medium przenika niemal przez wszystkie sfery życia codziennego. Jest narzędziem komunikacji interpersonalnej, przekazywania informacji i wiedzy, umożliwia nabywanie produktów i usług (zakupy przez Internet) czy zarządzanie finansami (bankowość elektroniczna). Obecnie coraz większa liczba firm w Polsce wykorzystuje Internet i powiązane z nim technologie komunikacyjno-informacyjne w działalności gospodarczej, głównie jako sposób dotarcia do nowych klientów i nowych rynków, w mniejszym zaś stopniu do realizacji transakcji kupna-sprzedaży [Talar i Kos-Łabędowicz 2014].

W Polsce Internet dokonał głębokiej transformacji szczególnie w takich sektorach, jak bankowość, handel oraz turystyka [Cichomski i in. 2011]. Z jednej strony przyczynił się do zwiększenia konsolidacji w branży turystycznej, a z drugiej stał się szansą dla właścicieli małych hoteli, pensjonatów, biur podróży, kwater prywatnych jako dostępna i tania forma komunikowania się z rynkiem. Dzięki Internetowi branża hotelarska uzyskała możliwość dotarcia do szerokiej grupy odbiorców nie tylko przez prezentację oferty, ale również przez sprzedaż produktów i usług klientom bezpośrednio poprzez witrynę internetową (rezerwację noclegu poprzez pocztę elektroniczną, wypełnienie i wysłanie formularza rezerwacyjnego lub rezerwację on-line).

Jak stwierdza E. Pitrus, w przedsiębiorstwach turystycznych można wyróżnić trzy stopnie zastosowania technologii teleinformatycznych: komunikacja z potencjalnym klientem (prezentacja oferty), rezerwacja (usługa, pakiet) i pełna transakcja elektroniczna (rezerwacja, potwierdzenie rezerwacji i płatność elektroniczna) [Pitrus 2007]. 
Z badań G. Cichomskiego wynika, iż własne serwisy internetowe posiada 90\% firm branży turystycznej [Cichomski i in. 2011]. Jeszcze w 2002 roku jedynie połowa hoteli w Polsce posiadała swoje witryny internetowe, a w 2005 roku odsetek ten sięgał już 83\% [Biełuszko 2007]. Obecnie właściwie każdy hotel ma własną witrynę internetową. Biura podróży, do niedawna sprzedające swoje usługi wyłącznie w tradycyjnych oddziałach [Rusiecki 2007], dziś oferują możliwość zakupu przez Internet i są niejednokrotnie liderami sprzedaży w sieci (Travelplanet, Rainbow Tours) [Dwornik 2013]. W Internecie zawierane jest już ponad 50\% transakcji zakupu biletów lotniczych [Cichomski i in. 2011].

Funkcje pełnione przez witryny internetowe w działalności gospodarczej można podzielić na [Król 2015]:

- informacyjną - prezentacja określonych treści,

- kontaktową - funkcja podstawowa, umożliwia kontakt oraz wymianę informacji między użytkownikiem witryny a jej administratorem/właścicielem,

- personalizującą - umożliwia użytkownikowi m.in. utworzenie indywidualnego konta, chronionego loginem i hasłem dostępu, dostosowanie wyglądu witryny do własnych potrzeb, publikowanie komentarzy i opinii, biuletyn nowości,

- rezerwacyjną - umożliwia rezerwację usługi za pomocą formularza kontaktowego,

- płatniczą - umożliwia transakcję oraz dokonanie płatności.

Współczesne witryny internetowe uległy więc wielu zmianom, nie zawierają już wyłącznie informacji natury statycznej (prezentacja treści), lecz także elementy dynamiczne świadczące o jej komunikowaniu się z użytkownikiem, tj. aktualności, formularze wysyłkowe, przyciski interaktywne, składanie zamówień w typie on-line, multimedia oraz linki do sieci społecznościowych.

Celem artykułu jest poznanie zakresu wykorzystania Internetu przez gospodarstwa agroturystyczne i identyfikacja funkcji, jakie Internet pełni w tych gospodarstwach. W opracowaniu poszukuje się odpowiedzi na następujące pytania badawcze:

- W jaki sposób gospodarstwa agroturystyczne prezentują siebie w Internecie?

- Czy witryna internetowa pełni jedynie funkcję informacyjną czy też stanowi narzędzie komunikowania się z klientem i zawierania transakcji kupna-sprzedaży?

\section{Metodyka badań}

Przedmiotem badania są witryny internetowe, określane także mianem serwisów internetowych (ang. website). Pojęcia te oznaczają grupę (zbiór) powiązanych ze sobą tematycznie i umieszczonych na jednym serwerze stron interneto- 
wych. Pojęcie strony internetowej (ang. webpage) odnosi zaś się do pojedynczego dokumentu internetowego w obrębie wielu stron całego serwisu.

Podstawową metodą oceny witryn internetowych firm branży turystycznej w literaturze zagranicznej jest extension Model of Internet Commerce Adoption (eMICA), uwzględniający specyfikę firm turystycznych, opracowany w 2000 roku przez J. Coopera i L. Burgess [Burgess i Cooper 2000] i zmodyfikowany w kolejnych latach przez Lin i innych (biura podróży) [2009] oraz Doolin i innych (lokalne organizacje turystyczne) [2002] i Platania (agroturystyka) [2014].

W modelu Coopera i Burgess wyodrębnia się trzy stadia rozwoju witryn internetowych. Witryna internetowa w stadium I ma charakter statyczny i jest wykorzystywana jako narzędzie prezentacji i promocji oferty turystycznej. Często wykorzystuje ona wyszukaną grafikę i zawiera wiele informacji, jednak nie jest źródłem wymiernych korzyści dla usługodawcy. Oznacza to, iż firma istnieje w Internecie wyłącznie w celach informacyjnych. W stadium II poprzez witrynę internetową klienci mogą uzyskać nie tylko informacje o firmie i ofercie, lecz również odpowiedzi na pytania $\mathrm{w}$ odniesieniu do produktów i cen (za pomocą email). Wreszcie w stadium III witryna internetowa umożliwia firmie zawieranie transakcji kupna sprzedaży, tj. sprzedaż on-line, płatność internetowa.

Zmodyfikowany model eMICA zastosowano do analizy i oceny witryn internetowych gospodarstw agroturystycznych w województwie podlaskim. Do oceny wykorzystano 40 zmiennych, odpowiednio przystosowanych do potrzeb badań. Sformułowane kryteria przedstawiono w tabeli 1.

\section{Tabela 1}

Zmodyfikowany Model of Internet Commerce Adoption (eMICA)

\begin{tabular}{|l|l|}
\hline \multicolumn{2}{|c|}{ Stadium I. Promocja } \\
\hline $\begin{array}{l}\text { Faza 1 - informa- } \\
\text { cje podstawowe }\end{array}$ & $\begin{array}{l}\text { nazwa gospodarstwa, adres, numer telefonu, mapa, GPS, galeria } \\
\text { usług lub produktów }\end{array}$ \\
\hline $\begin{array}{l}\text { Faza 2 - informa- } \\
\text { cje rozszerzone }\end{array}$ & $\begin{array}{l}\text { logo, adres e-mail, informacje o gospodarstwie, informacje o gminie/ } \\
\text { /regionie, aktualności }\end{array}$ \\
\hline \multicolumn{2}{|c|}{ Stadium II. Funkcjonalność (interaktywność z użytkownikiem) } \\
\hline $\begin{array}{l}\text { Faza 3 - niska } \\
\text { interaktywność }\end{array}$ & $\begin{array}{l}\text { katalog usług podstawowych (tj. usługi noclegowe, wyżywienie) i do- } \\
\text { datkowych, cennik, strona www w języku angielskim i innym, linki do } \\
\text { miejsc w regionie i linki do innych ofert }\end{array}$ \\
\hline $\begin{array}{l}\text { Faza 4 - średnia } \\
\text { interaktywność }\end{array}$ & $\begin{array}{l}\text { oferta pakietowa (tj. wycieczka, spływ i inne), formularz kontaktowy, } \\
\text { kontakt przez Skype, informacja o pogodzie, księga gości, aktualiza- } \\
\text { cja strony www, broszury, kamera internetowa, certyfikat jakości }\end{array}$ \\
\hline $\begin{array}{l}\text { Faza 5 - wysoka } \\
\text { interaktywność }\end{array}$ & $\begin{array}{l}\text { przekierowanie na portal społecznościowy, multimedia, opcje: „napisz } \\
\text { opinię”, „,lubię to”, „udostępnij”, panorama gospodarstwa 360, RSS }\end{array}$ \\
\hline \multicolumn{2}{|l|}{ Stadium Ill. Dojrzałość procesu transakcji handlowej } \\
\hline Faza 6 - transakcja & $\begin{array}{l}\text { formularz rezerwacji, rezerwacja on-line (z kartą kredytową lub bez } \\
\text { karty), płatność on-line }\end{array}$ \\
\hline
\end{tabular}

Źródło: Opracowanie własne na podstawie Platania [2014, s. 54-56]. 
Adresy witryn internetowych poddanych ocenie pozyskano z wykorzystaniem wyszukiwarki internetowej Google, poprzez wpisywanie w wyszukiwarce haseł przedmiotowych: ,agroturystyka” z dopiskiem nazwy województwa oraz z katalogów tematycznych.

W ramach badania przeprowadzono analizę 63 witryn internetowych gospodarstw agroturystycznych województwa podlaskiego. Oceniano w kolejnych etapach: zakres informacji podstawowych i poszerzonych, poziom interaktywności witryny oraz możliwość rezerwacji i zawarcia transakcji płatniczej. Na tej podstawie określono, w jakim stadium interaktywności jest witryna internetowa oraz jaką funkcję pełni w prowadzeniu gospodarstwa agroturystycznego (jako instrument promocji, komunikowania się z klientem, bądź zawierania transakcji kupna-sprzedaży).

\section{Wykorzystanie Internetu przez gospodarstwa agroturystyczne}

Agroturystyka jest specyficzną formą wypoczynku i aktywności gospodarczej. Jak wynika z raportu Ministerstwa Rolnictwa i Rozwoju Wsi, jest ona obecnie najchętniej podejmowaną formą pozarolniczej działalności gospodarczej na terenach wiejskich (30\% ogółu gospodarstw) [MRiRW 2015], a jednocześnie - niszową formą turystyki. Rozwija się głównie w regionach atrakcyjnych turystycznie, w niewielkiej skali na obszarach rolniczych, gdzie jest zazwyczaj jedyną formą świadczenia usług noclegowych [Bednarek-Szczepańska i Bański 2014]. Stąd też największa koncentracja gospodarstw agroturystycznych ma miejsce w pięciu województwach: podkarpackim (985), małopolskim (1327) oraz warmińsko-mazurskim (801), podlaskim (625) i pomorskim (672) [MRiRW 2015]. Trudno jest jednoznacznie określić liczbę gospodarstw agroturystycznych, ponieważ wiele ich ubywa, ale też dużo powstaje nowych, które nie są rejestrowane lub promują się jedynie w Internecie [Wojciechowska 2011]. Wśród 8 tys. obiektów agroturystycznych funkcjonujących na terytorium Polski przeważają kwatery agroturystyczne (pokoje gościnne) [Jagusiewicz i Byszewska-Dawidek 2010], o bardzo różnym standardzie jakościowym (przeważają kwatery o najniższym standardzie), które traktowane są jako dodatkowa działalność.

Wykorzystanie Internetu w działalności agroturystycznej na tle innych form działalności turystycznej jest niewystarczające. Wynika to w szczególności z faktu, iż gospodarstwa agroturystyczne to sektor zdominowany przez małe firmy rodzinne. Odzwierciedlają one zatem ogólną sytuację w Polsce, gdzie według danych GUS, prawie 40\% małych firm wciąż nie posiada własnej witryny 
internetowej [GUS 2014]. Jej brak jest uzasadniany przez właścicieli małych i średnich firm następującymi powodami:

- brakiem wiedzy technicznej do samodzielnego zarządzania witryną (zamieszczanie informacji, modyfikacje, aktualizowanie treści itd.),

- brakiem czasu na zarządzanie witryną,

- ograniczonym budżetem,

- posiadaniem tzw. wizytówki, czyli małej witryny informacyjnej, zawierającej dane teleadresowe i wskazówki dojazdu, bez szczegółowej prezentacji oferty czy kompleksowego jej opisania.

Niewielkie zainteresowanie kwaterodawców prowadzeniem własnej witryny internetowej gospodarstwa agroturystycznego potwierdzają badania przeprowadzone $\mathrm{w}$ różnych regionach kraju. $\mathrm{Z}$ badań przeprowadzonych przez J. Kosmaczewską w 2010 roku wynika, że w województwie wielkopolskim zaledwie $21 \%$ gospodarstw agroturystycznych posiadało własną witrynę internetową [Kosmaczewska 2010]. Badania przeprowadzone przez T. Dziechciarza w województwie lubelskim w 2010 roku (na próbie 134 gospodarstw agroturystycznych) wykazały, że witryny internetowe pełnią głównie funkcję informacyjna, chociaż zakres informacji na stronach i ich jakość nie są w pełni zadawalające [Dziechciarz 2011]. Z kolei K. Stepaniuk badając obecność gospodarstw agroturystycznych województwa podlaskiego w Internecie, wskazuje, że większość $\mathrm{z}$ nich zamieszcza informację o prowadzonej przez siebie działalności $\mathrm{w}$ ramach ogólnopolskich portali turystycznych lub internetowych katalogów firm, a niewielka część prowadzi własne strony www [Stepaniuk 2009]. Jak wynika z badań innych autorów, witryny internetowe gospodarstw agroturystycznych województwa podlaskiego nie spełniają w większości minimalnych kryteriów związanych zarówno z zawartością witryny, jej estetyką, parametrami technicznymi, jak i samą ofertą [Krzyżanowska i Wojtkowski 2012]. Najnowsze wyniki badań 300 witryn internetowych (po $100 \mathrm{z}$ województw warmińsko-mazurskiego, małopolskiego oraz podkarpackiego) w 2015 roku wykazały, że witryny internetowe pełnią funkcje informacyjne, marketingowe oraz kontaktowe. Jedynie co piąta witryna pełniła funkcję rezerwacyjną [Król 2015]. Artykuł jest kolejną próbą analizy widoczności gospodarstw agroturystycznych w Internecie.

\section{Wyniki badań własnych funkcjonalności stron internetowych gospodarstw agroturystycznych}

Najprostszym sposobem zaistnienia przedsiębiorstwa na rynku internetowym i w świadomości jego użytkowników jest stworzenie własnej witryny internetowej. 
W przypadku całej zbiorowości gospodarstw agroturystycznych własną witrynę internetową posiadało $12,3 \%$ podmiotów (63 obiekty z 517 ) i te obiekty poddano dalszym analizom. Pozostałe obiekty (454) zamiast witryny internetowej posiadały wizytówkę firmy, zamieszczoną na krajowych lub regionalnych portalach internetowych (tj. www.zielonewrota.pl, www.zielonakwatera.pl, http://agroturystyka.irrt.pl, http://www.kwatery-prywatne.net, https://e-turysta. net, http://www.holidaycheck.pl, booking.com) i serwisach jednostek samorządu terytorialnego (powiatów i gmin).

Witryna typu wizytówka ma zazwyczaj dość ograniczoną funkcjonalność - zawiera niewiele tekstu, nie opisuje w pełni oferty, nie zawiera wystarczającej liczby zdjęć, które uwiarygodniają firmę w wirtualnym świecie. Jest jednak najtańszym i najprostszym instrumentem promocji. W opinii A. Jasińskiego portale agroturystyczne, na których umieszczane są wizytówki gospodarstw agroturystycznych, nie są dobrze pozycjonowane w wyszukiwarkach, co skutkuje tym, że potencjalni turyści rzadko trafiają na takie strony po wpisaniu ogólnych zapytań [Jasiński 2012]. W przypadku agroturystyki i badanej zbiorowości gospodarstw, witryny-wizytówki cieszą się jednak ogromną popularnością i zaufaniem kwaterodawców.

Największa liczba gospodarstw, które posiadały własną witrynę internetowa, była zlokalizowana w powiatach: sokólskim (9), hajnowskim (15) i monieckim (9). Aktywność kwaterodawców w Internecie wynika prawdopodobnie z zaangażowania lokalnych organizacji, funkcjonujących na obszarach tych powiatów, tj. Białowieskie Stowarzyszenie Agroturystyczne, Agroturystyczne Stowarzyszenie „Puszcza Białowieska” i Podlaskie Stowarzyszenie Agroturystyczne. Podkreślają to wyniki badań J. Zawadki na Lubelszczyźnie, z których wynika, że gminy charakteryzujące się wyższym poziomem rozwoju agroturystyki to gminy, na terenie których funkcjonują aktywnie działające stowarzyszenia agroturystyczne oraz lokalne organizacje turystyczne [Zawadka 2010].

Ocenę witryn internetowych gospodarstw prowadzono poprzez sprawdzenie obecności lub braku ( 1 - jest, 0 - nie ma) zmiennych, uwzględnionych w modelu eMICA.

Większość badanych gospodarstw umieszcza na witrynie internetowej informacje, które reprezentują stadium I (fazę 1 lub 2). Ta pierwsza grupa zmiennych, obejmująca takie elementy jak: nazwa własna gospodarstwa, lokalizacja w przestrzeni (mapa), numer telefonu i kontakt e-mail, a także opis gospodarstwa i regionu $\mathrm{z}$ atrakcjami i galerią zdjęć, jest niezbędna w fazie 1 kontaktu $\mathrm{z}$ potencjalnym klientem, ponieważ pozwala mu uzyskać wszelkie użyteczne informacje służące zaplanowaniu podróży. Wyniki oceny zamieszczono w tabeli 2.

W województwie podlaskim wszystkie witryny internetowe badanych gospodarstw agroturystycznych posiadały informacje typowe dla stadium I, tj. ad- 
Tabela 2

Charakterystyka stadium I z podziałem na fazy

\begin{tabular}{|l|c|}
\hline Faza 1 - informacje podstawowe & \% gosp. \\
\hline Adres & 100 \\
Numer telefonu & 100 \\
Galeria zdjęć & 100 \\
Nazwa gospodarstwa & 65,0 \\
Mapa Google & 74,6 \\
Jak dojechać (opis) & 33,3 \\
Dane GPS & 39,6 \\
\hline Faza 2 - informacje rozszerzone & $\%$ gosp. \\
\hline Informacja o gospodarstwie & 100 \\
Kontakt e-mail & 96,8 \\
Atrakcje w okolicy/regionie & 73,0 \\
Logo & 46,0 \\
Aktualności & 17,4 \\
\hline
\end{tabular}

Źródło: Badania własne.

res $(100 \%)$, numer telefonu $(100 \%)$, galerię zdjęć (100\%) oraz nazwę własną gospodarstwa (100\%). W przypadku badanej zbiorowości nazwa gospodarstwa, poza kilkunastoma wyjątkami, gdzie wykorzystano wyłącznie nazwiska właścicieli, podkreślała specyfikę gospodarstwa (np. gospodarstwo Magiczny Zakątek, Zielona Dolina). Większość gospodarstw wskazywało lokalizację na mapie (74,6\%), opisywało jak dojechać (własna mapa), a prawie połowa $(39,6 \%)$ podawała dane do nawigacji (GPS).

O przejściu witryny internetowej do fazy 2 świadczy zamieszczanie dodatkowych informacji, tj. logo gospodarstwa, kontakt e-mail, opis gospodarstwa, opis atrakcji w najbliższej okolicy oraz aktualności.

Przeprowadzone badania wykazały, że wszystkie gospodarstwa zamieszczają w posiadanej witrynie opis gospodarstwa $(100 \%)$, większość - adres poczty elektronicznej $(96,8 \%)$ oraz informacje na temat głównych atrakcji turystycznych w okolicy/regionie (73\%). Nie wszystkie jednak z badanych gospodarstw zamieszczają znak graficzny - logo $(46,0 \%)$, który jest bardzo pożądanym elementem witryny internetowej, ponieważ pełni funkcję swoistego wyróżnika gospodarstwa na tle konkurencji. Nieliczne witryny internetowe mają wyodrębniony dział aktualności $(17,4 \%)$.

Kolejne stadium zaawansowania witryny internetowej dotyczy jej interaktywności, czyli zdolności oddziaływania na siebie komunikujących się stron (kwaterodawcy i turysty), poprzez przekazywanie informacji i reagowanie na nią. Jej celem jest zmniejszenie dystansu między światem wirtualnym a realnym. Wyniki analiz stadium II, z podziałem na fazy przedstawia tabela 3 . 
Tabela 3

Zmienne stadium II z podziałem na fazy

\begin{tabular}{|l|c|}
\hline \multicolumn{1}{|c|}{ Faza 3 - niska interaktywność } & Odsetek [\%] \\
\hline Informacja o ofercie (opis i zdjęcia) & 100 \\
Informacja o dodatkowych usługach & 66,6 \\
Cennik & 65,0 \\
Strona w języku angielskim & 63,8 \\
Strona w trzech wersjach językowych (poza angielską i polska) & 33,3 \\
Linki do miejsc które warto zobaczyć & 3,17 \\
Linki do innych ofert turystycznych & 23,8 \\
\hline \multicolumn{1}{|c|}{ Faza 4 - średnia interaktywność } & 3,17 \\
\hline Komunikator Skype & \\
Aktualizacja strony www & 53,3 \\
Formularz kontaktowy & 46,0 \\
Księga gości & 42,8 \\
Informacja o pogodzie & 19,0 \\
Certyfikat jakości wydawany przez PFTW „GG” & 3,17 \\
Certyfikat jakości wydawany przez inne instytucje & 3,17 \\
Pakiety (oferta poszerzona) & 22,2 \\
Broszury w pdf & 19,0 \\
Kamera internetowa & - \\
\hline \multicolumn{1}{|c|}{ Faza 5 - wysoka interaktywność } & - \\
\hline Strona na portalach społecznościowych & \\
Galeria multimedialna & 11,1 \\
Napisz opinię & 12,6 \\
Przycisk „lubię to” & 7,9 \\
Przycisk „udostępnij” & 4,76 \\
Panorama gospodarstwa 360 & 3,17 \\
RSS & 1,58 \\
\hline
\end{tabular}

Źródło: Badania własne.

W fazie 3, która określa niską interaktywność witryny, pełni ona nadal głównie funkcję informacyjną. Powinien znaleźć się na niej szczegółowy opis oferty turystycznej gospodarstwa, w tym opis bazy noclegowej (obiektu, pomieszczeń sypialnych), oferty żywieniowej, opis dodatkowych usług (np. rowery, kajaki, ognisko, grill, plac zabaw, animacje itd.) oraz cennik oferowanych usług. Ponadto witryna powinna być prowadzona dodatkowo w języku obcym. Nowoczesne witryny internetowe zawierają linki do miejsc, które warto zobaczyć w regionie oraz linki do innych ofert turystycznych w okolicy (np. linki do innych obiektów noclegowych, gastronomicznych, oferty lokalnego biura podróży lub PTTK).

W przypadku badanych gospodarstw wszystkie $(100 \%)$ witryny internetowe zawierały opis podstawowej oferty turystycznej. Informacje o dodatkowych usługach zamieściło $66,6 \%$, a cennik $65 \%$ obiektów. Odsetek gospodarstw po- 
siadających witryny, które dodatkowo zawierały informacje $w$ języku angielskim wynosił $63,8 \%$, a w co najmniej dwóch językach obcych - zaledwie 33\%. Podlaskie gospodarstwa agroturystyczne stosunkowo rzadko zamieszczały na swoich witrynach linki do miejsc wartych zobaczenia $(23,8 \%)$ oraz linki do innych ofert turystycznych z najbliższej okolicy $(3,17 \%)$.

Fazę 4, która określa średnią interaktywność witryny, charakteryzują narzędzia, które ułatwiają dwustronną komunikację oraz przybliżają potencjalnego turystę do decyzji zakupu, takie jak: formularz kontaktowy, księga gości, kontakt przez Skype, informacja o pogodzie, kamera internetowa, broszury do pobrania, a także certyfikaty jakości czy też pakiety pobytowe skierowane do konkretnych grup klientów. Badane gospodarstwa oferowały kontakt telefoniczny przez Skype $(53,3 \%)$, a 42,8\% zamieszczało w witrynie internetowej formularz kontaktowy. Niewielki był odsetek witryn internetowych zawierających informacje o pogodzie (3,17\%) oraz księgę gości (19\%), zaś żadna z nich nie udostępniała możliwości pobierania materiałów promocyjnych (w formacie pdf) oraz obserwacji obiektu przy wykorzystaniu kamery internetowej.

Wyznacznikiem poziomu interaktywności jest dodatkowo informacja o certyfikacie bądź dyplomie poświadczającym jakość oferowanych usług. Wśród badanych gospodarstw tylko dwa zamieściły informację o posiadanym certyfikacie jakości wydanym przez Polską Federację Turystyki Wiejskiej „Gospodarstwa Gościnne”, a 11 gospodarstw zamieściło informację o certyfikatach i dyplomach uzyskanych zazwyczaj w związku z prowadzeniem gospodarstwa ekologicznego. Brak zainteresowania kategoryzacją obiektów agroturystycznych wśród kwaterodawców jest problemem, który występuje nie tylko w regionie podlaskim, lecz także w skali całego kraju. Według danych z 2012 roku, certyfikacja objętych było około 20\% kwater na obszarach wiejskich [Bański 2012].

Ostatnim wyznacznikiem interaktywności witryny (ocenianej w fazie 4) jest zamieszczanie gotowych pakietów pobytowych (turystycznych), oferowanych turystom po zryczałtowanej cenie. Jak wynika z badań, pakiety turystyczne za pośrednictwem witryny internetowej oferowało zaledwie $19 \%$ badanych gospodarstw.

W fazie 5, która określa wysoką interaktywność, poprzez umożliwienie dwukierunkowej komunikacji niemal „na żywo”, witryna internetowa jest powiązana $\mathrm{z}$ mediami społecznościowymi. $\mathrm{W}$ toku badań zidentyfikowano kilka gospodarstw, które zarządzały własną stroną (ang. fanpage) w serwisie społecznościowym Facebook (11,1\%), lub też zapraszały użytkowników do interakcji poprzez wykorzystanie opcji ,lubię to" $(4,76 \%)$ i ,udostępnij” (3,17\%). Sporadycznie występowały takie elementy witryn, jak: galerie multimedialne $(12,6 \%)$, opcja „napisz opinię” (7,9\%), panorama gospodarstwa 360 (1,58\%) oraz kanał RSS (ang. RDF Site Summary) (1,58\%). 
Ostatnim etapem badań była ocena możliwości zawierania transakcji z wykorzystaniem strony internetowej (stadium III). Na tym etapie można ocenić, czy gospodarstwa agroturystyczne wykorzystują stronę internetową do zawierania transakcji (tab. 4).

\section{Tabela 4}

Zmienne stadium III z podziałem na fazy

\begin{tabular}{|l|c|}
\hline Faza 6 - transakcja & Odsetek [\%] \\
\hline Formularz rezerwacji & 3,17 \\
Rezerwacja on-line z karta kredytowa & - \\
Rezerwacja on-line bez karty kredytowej & - \\
Płatność on-line & - \\
\hline
\end{tabular}

Źródło: Badania własne.

Z badań wynika, iż gospodarstwa agroturystyczne nie wykorzystują Internetu do bezpośredniej sprzedaży oferty oraz zawierania transakcji on-line. Rezerwacja odbywa się telefonicznie bądź przy wykorzystaniu formularza kontaktowego. Jedynie jedno gospodarstwo spośród badanych posiadało $\mathrm{w}$ witrynie internetowej formularz rezerwacji umożliwiający wybór optymalnego terminu, bez możliwości samodzielnej rezerwacji, a jedno gospodarstwo - przekierowanie na portal komercyjny (booking.com).

\section{Podsumowanie}

Przeprowadzone badania wykazały, że większość gospodarstw agroturystycznych zamieszczała informację o prowadzonej działalności w ramach ogólnopolskich i regionalnych portali agroturystycznych, a tylko niewielka ich liczba $(12,3 \%)$ posiadała własne witryny internetowe. Analizowane witryny internetowe miały w większości charakter statyczny i pełniły jedynie funkcję informacyjną.

Nieliczne witryny internetowe są przykładem zastosowania nowoczesnych, interaktywnych narzędzi komunikacji z klientem, do których należy przede wszystkim strona w serwisie społecznościowym, formularze kontaktowe oraz aktualności.

Należy rekomendować podjęcie, przez organizacje wspierające rozwój agroturystyki, działań informacyjnych i edukacyjnych, popularyzujących wykorzystywanie witryn internetowych przez kwaterodawców. Należy bowiem liczyć się z coraz popularniejszym zjawiskiem zakupu ofert turystycznych za pośrednictwem Internetu, preferowanym przez turystów. 


\section{Literatura}

BAŃSKI J., 2012: Turystyka wiejska, w tym agroturystyka, jako czynnik zrównoważonego $i$ wielofunkcyjnego rozwoju obszarów wiejskich, Agrotec Polska i IGiPZ, Warszawa.

BEDNAREK-SZCZEPAŃSKA M., BAŃSKI J., 2014: Lokalizacyjne uwarunkowania oferty gospodarstw agroturystycznych w Polsce, Przegląd Geograficzny 2 (86), 245.

BIEŁUSZKO K., 2007: Kanały dystrybucji na elektronicznym rynku ustug hotelarskich $w$ Polsce, [w:] W. Kurek, R. Palusiński (red.), Studia nad turystyka. Prace ekonomiczne i społeczne. Geograficzne, ekonomiczne i społeczne aspekty turystyki, Instytut Geografii i Gospodarki Przestrzennej, Uniwersytet Jagielloński, Kraków, 14.

BURGESS L., COOPER J., 2000: Extending the viability of MICA (model of internet commerce adoption) as a metric for explaining the process of business adoption of internet commerce, Paper Presented at the International Conference on Telecommunications and Electronic Commerce, Dallas.

CICHOMSKI G., HUTTEN-CZAPSKI F., RAŁ M., SASS W., 2011: Polska internetowa. Jak Internet dokonuje transformacji polskiej gospodarki, Boston Consulting Group, Warszawa.

DOOLIN B., BURGESS L., COOPER J., 2002: Evaluating the use of the Web for tourism marketing: a case study from New Zealand, Tourism Management 23 (5), 557-561.

DWORNIK B., 2013: Wakacje przez Internet. Raport Interaktywnie.com. Dostępne on-line na portalu http://interaktywnie.com.

DZIECHCIARZ T., 2011: Wykorzystanie witryn internetowych i poczty elektronicznej w marketingu agroturystyki na przykładzie województwa lubelskiego, Nierówności Społeczne a Wzrost Gospodarczy 23, 30-39.

GUS, 2014: Wykorzystanie technologii informacyjno-telekomunikacyjnych w przedsiębiorstwach $i$ gospodarstwach domowych w 2014 r., Warszawa.

JAGUSIEWICZ A., BYSZEWSKA-DAWIDEK M., 2010: Turystyka wiejska w 2010 roku, Instytut Turystyki, Warszawa.

JASIŃSKI A., 2012: Skuteczność promocji z wykorzystaniem internetowych portali agroturystycznych $w$ świetle opinii ich użytkowników. Model portalu internetowego dla regio$n u$, Acta Innovations 4, 56.

KOSMACZEWSKA J., 2010: Witryna internetowa jako narzędzie kreowania konkurencyjności w agroturystyce, Acta Scientiarum Polonorum, Oeconomia 9 (4), 225-232.

KRÓL K., 2015: Funkcjonalność oraz funkcje internetowych witryn gospodarstw agroturystycznych, Economics and Management 1, 345.

KRZYŻANOWSKA K., WOJTKOWSKI R., 2012: Rola Internetu w promocji ustug agroturystycznych, Studia Ekonomiczne i Regionalne 5, 1, 48.

LIN D., ZHOU Z., GUO X., 2009: A Study of the Website Performance of Travel Agencies Based on the EMICA Model, J. Service Science \& Management 3, 181-185.

MRiRW, 2015: Rolnictwo i gospodarka żywnościowa w Polsce, Warszawa.

PITRUS E., 2007: Internet w polskiej turystyce, Prace Geograficzne 117, 278.

PLATANIA M., 2014: Agritourism Farms and the Web. An Exploratory Evaluation of their Websites, Agris on-line Papers in Economics and Informatics 6, 3, 54-56. 
RUSIECKI P., 2007: Analiza funkcjonowania serwisów internetowych biur podróży na rynku organizatorów imprez turystycznych w Polsce, [w:] T. Porębska-Miąc, H. Sroka (red.), Systemy Wspomagania Organizacji, Wyd, AE Katowice, Katowice.

STEPANIUK K., 2009: Ocena funkcjonalności wybranych witryn internetowych promujacych działalność agroturystycznq w woj. podlaskim, Ekonomia i Zarządzanie 1, 131.

TALAR S., KOS-ŁABĘDOWICZ J., 2014: Internet $w$ działalności polskich przedsiębiorstw. Studia Ekonomiczne, 184, 138.

WOJCIECHOWSKA J., 2011: 20 lat polskiej agroturystyki - o przeszłości i przyszłości. Turyzm 21 (1-2), 69.

ZAWADKA J., 2010: Ekonomiczno-spoteczne determinanty rozwoju agroturystyki na Lubelszczyźnie, Wyd. SGGW, Warszawa.

\section{Abstrakt}

Celem artykułu jest ocena witryn obiektów agroturystycznych i sposobu ich wykorzystania $\mathrm{w}$ promocji i dystrybucji oferty turystycznej. Analizie poddano 63 witryny internetowe obiektów agroturystycznych z obszaru województwa podlaskiego. Do oceny stron wykorzystano model eMICA, stosowany m.in. do oceny witryn internetowych podmiotów branży turystycznej i dostosowany do warunków polskich. Badano rodzaj i zakres informacji, poziom interaktywności strony oraz możliwość zawierania transakcji handlowych. Przeprowadzone badania wskazuja, że w zbiorowości gospodarstw agroturystycznych zdecydowanie dominuje grupa, która wykorzystuje witryny internetowe wyłącznie w celu prezentacji i promocji oferty (strona zawiera podstawowe informacje na temat oferty).

Słowa kluczowe: Internet, agroturystyka, witryna internetowa, województwo podlaskie

\section{Website as a tool for the promotion and distribution of agritourism offer}

\section{Abstract}

This paper evaluates 63 agritourism websites in Podlaskie province to analyse their role in promotion and distribution of tourism offer. This study uses the eMICA methodological approach (adapted to Polish conditions ) used to evaluate websites from the tourist sector. The results indicate that the most of agritourism farms use the Internet sites only for the purpose of presentation and promotion of the offer (they contain only basic information about the offer).

Key words: Internet, agritourism, www website, Podlaskie province 